\title{
THE RECENT FINANCIAL CRISIS AND ITS IMPACT ON INTEREST RATE SWAPS: A ROAD TO RECOVERY THROUGH THE FRUSTRATION OF COMMERCIAL PURPOSE DOCTRINE
}

\author{
Zachary Ahonen* \\ I. INTRODUCTION
}

The global financial crisis of 2007 and 2008 continues to affect many different aspects of the financial industry; everything from governmental regulations to the number of players in a once robust lending market. In June 2009, the US Department of the Treasury described the situation, saying, "Over the past two years we have faced the most severe financial crisis since the Great Depression." "Different parties pointed the figurative finger at one institution or another as being the culprit responsible for the damage, but it was not a single factor; rather, it was a combination of excessive speculation and egregious wrong-doing by a multitude of entities. $^{2}$ The derivatives market was front-and-center in this ordeal, with some of the more detailed and complicated derivatives lying at the heart of the financial meltdown. ${ }^{3}$ This Note deals with vanilla interest rate swaps, the simplest form of derivative, ${ }^{4}$ and the financial crisis' effects on both parties to interest rate swap transactions. Despite the so-called simplistic or vanilla nature of traditional interest rate swaps, this Note discusses the financial downturn's drastic and complicated effect on these transactions.

First, this Note provides a general overview of the derivatives market-interest rate swaps more specifically-and the financial crisis' actual effect on the swaps. Second, this Note discusses the causes of action both American and British parties negatively affected by the swaps have brought in court and the manner in which the courts have disposed of these cases. As this Note will discuss, these traditional causes of action have almost exclusively failed in America, providing little consolation for the losers in these transactions. Third, this Note explains the doctrine of frustration of commercial purpose. Fourth and finally, this Note advocates the effectiveness of the doctrine of frustration of commercial purpose as a means of financial recovery for the losers in interest rate swaps during the

* Zachary Ahonen is a 2014 J.D. graduate of the Indiana University Robert H. McKinney School of Law. The author would like to give special thanks to Erik D. Bigelow for his assistance with topical and theoretical expertise.

1. Daniel J. Morrissey, After the Meltdown, 45 Tulsa L. Rev. 393, 396 (2010).

2. Id. at 397.

3. Id at 408 .

4. Thomas J. Molony, Still Floating: Security-Based Swap Agreements After DoddFrank, 42 Seton Hall L. ReV. 953, 954 (2012). 
financial crisis.

\section{THE ONE HundRED FoOt VIEW OF DERIVATIVES, INTEREST RATE SWAPS, AND THE FINANCIAL CRISIS}

\section{A. An Overview of the Derivatives Market}

In order to fully appreciate the inner workings of interest rate swaps, it is essential to have an understanding of derivatives in general. A derivative is the name given to a financial instrument that derives its value from something else. ${ }^{5}$ Derivatives come in many forms including, for example: credit default swaps, credit linked notes, basket default swaps, synthetic collateralized debt obligations, currency swaps, and of course, interest rate swaps. ${ }^{6}$ Swaps are just one of the broad categories of financial derivatives and are further divided into two classifications: commodity swaps and financial swaps. ${ }^{7}$ Commodity swaps involve the swapping of products such as crude oil or grain. ${ }^{8}$ Financial swaps involve the exchange of bonds, foreign currencies, stocks, or other financial assets or liabilities. ${ }^{9}$ There are three types of financial swaps: foreign currency swaps, interest rate swaps, and equity swaps. ${ }^{10}$ As evidenced simply by the sheer number of derivatives within the swap category, the financial realm of derivatives can be confusing and tedious. In recognition of that complexity, this Note focuses solely on interest rate swaps to illustrate the overall applicability of a frustration of purpose cause of action.

\section{B. An Overview of Interest Rate Swaps: One of the Most Common Forms of Derivatives}

An interest rate swap involves two parties exchanging interest rate streams from two separate debt instruments. ${ }^{11}$ For example, if "Business A" needs to obtain capital, they may sell a debt bond and receive capital at a floating interest rate. The prospect of maintaining a floating rate on the loaned principal obviously creates a certain risk to Business A, so it may

5. Michael S. Bennett \& Michael J. Marin, The Casablanca Paradigm: Regulatory Risk in the Asian Financial Derivatives Market, 5 StAn. J.L. Bus. \& Fin. 1, 12 (1999).

6. See generally Jongho Kim, From Vanilla Swaps to Exotic Credit Derivatives: How to Approach the Interpretation of Credit Events, 13 FORDHAM J. CORP. \& FIN. L. 705 (2008).

7. Id. at 727 .

8. Id.

9. Id.

10. $I d$.

11. Stuart Somer, A Survey of Legal and Regulatory Issues Relevant to Interest Rate Swaps, 4 DePaul BuS. L.J. 385, 387 (1992). Note that in addition to two party swaps, there are also three party swaps involving a bank as an intermediary between the other two parties. For simplification purposes, this example is portrayed as a two-party swap. 
desire to hedge that risk. One option is to engage in an interest rate swap, which will allow Business A to "manage [its] financial risks" and "protect [itself] against unfavorable market movements." "For purposes of this hypothetical, the interest rate Business A has agreed to through its bond is called the "Corporate Bond Rate."13

Financial institutions or other entities recognize that they are in a more favorable position to take on the high-risk, high-reward gamble of carrying a variable rate. ${ }^{14}$ As a result, "Swap dealers aggressively market their transactions . ..."15 A bank or financial institution, for purposes of this hypothetical named "Bank 1," will offer to exchange with Business A the Corporate Bond Rate for a "fixed" interest rate. In this transaction, no money will exchange hands as a result of the principal but only as part of the interest differential. This is a so-called off-balance sheet transaction. ${ }^{16}$

In this hypothetical transaction, there will be three pertinent interest rates. The first is the aforementioned Corporate Bond Rate, which is a floating rate. It is important to recognize that this rate stays with Business A and does not affect Bank 1 in this transaction. The second relevant interest rate is the standard floating rate index, or simply the rate index. ${ }^{17} \mathrm{~A}$ very common rate index in swap transactions is LIBOR, or the London Interbank Offered Rate, which is tied to the rate at which large banking institutions can get loans for themselves at a single point in time. ${ }^{18}$ In this hypothetical, assume that Bank 1 and Business A agree that the swap will be tied to LIBOR as the index rate. The third and final relevant interest rate is the fixed rate. This is the rate that Bank 1 provides to Business A to hedge or counterbalance Business A's floating Corporate Bond Rate. The parties agree to a notional amount of principal for each term of the transaction, which the LIBOR rate will eventually be multiplied against to determine which party will owe an interest payment to the other for that term. ${ }^{19}$ The

12. Bennett \& Marin, supra note 5, at 18 (alterations added).

13. The examples in this Note are merely illustrative; they are not a comprehensive or full description of the details comprising an interest rate swap. After all, these transactions are complex; therefore, the examples are intended to be simplistic in order to demonstrate specific aspects of the transactions. There may be inaccuracies as a result, but this Note's primary focus is on applying the general mechanisms at work to the frustration of purpose doctrine.

14. Somer, supra note 11, at 388; see also Dan Fischer, WPPSS and Hammersmith: Increased Credit Risk Protection Resulting from Unprecedented Defaults, 9 ARIZ. J. INT'L \& CoMP. L. 513, 521 (1992).

15. Frank Partnoy, The Shifting Contours of Global Derivatives Regulation, 22 U. PA. J. INT'L. ECON. L. 421, 442 (2001) (alteration added).

16. Kim, supra note 6 , at 727.

17. Somer, supra note 11, at 387.

18. Somer, supra note 11 , at 387 . There are multiple LIBOR rates tied to different time frames and currencies. Assume for the purposes of this Note and more specifically this example that LIBOR refers to the three-month LIBOR rates for the US dollar.

19. Molony, supra note 4. 
amount of principal tied to an individual term likely will vary and can be used as a strategic means for one party or the other to project which periods might bring higher reward for that party. ${ }^{20}$

To clarify the transaction, an injection of numbers into the hypothetical is helpful. ${ }^{21}$ First, Business A takes out a corporate bond for $\$ 100$ at the floating Corporate Bond Rate from "Bank 2." Next, Bank 1 and Business A agree to use LIBOR as the index rate. It is crucial to recognize that LIBOR (or the chosen index rate) must track the Corporate Bond Rate very closely to effectively allow for Business A to hedge its interest risks. Bank 1 provides Business A with a fixed rate of 5 percent for each of four terms. Each term will relate to twenty-five dollars of the principal and will be spaced evenly throughout the duration of the loan. At the end of the first term, LIBOR happens to be 4 percent. What this means is that Bank 1 has won this term, and Business A will make a twenty-five cent payment to Bank $1 .^{22}$ At the end of the second term, LIBOR ends at 7 percent. That would mean that Business A has won this term, and Bank 1 will make a fifty cent payment to Business $\mathrm{A} .^{23}$

The last two terms will operate in the same manner, with the LIBOR rate ending above the fixed rate as a win for Business A and the LIBOR rate ending below the fixed rate as a win for Bank 1 . This works as a hedge for Business A in this way: if LIBOR rises to 10 percent for a term, then in a properly functioning swap, the Corporate Bond Rate will be right around 10 percent as well. Business A will receive a payment from Bank 1 roughly equivalent to what it must pay for that term of the bond to the original lending institution, Bank 2; thus, Business A approximately breaks even or hedges its risk.

If LIBOR falls to 2 percent for a term, then in a properly functioning swap, the Corporate Bond Rate will be right around 2 percent as well. Business A will pay Bank 1 roughly the equivalent to the amount it would have had to pay to Bank 2 as interest on the Corporate Bond Rate had it been equal to the fixed rate at 5 percent. In this way, Business A effectively pays 5 percent interest regardless of the way LIBOR moves; the variable within the transaction is whether Bank 1 is paying for any excess interest over 5 percent during that term or whether Business A is paying Bank 1 for

20. Molony, supra note 4 .

21. Once again, the author acknowledges that this hypothetical and the numbers presented suffer from simplicity; however, the necessary functions of the interest rate swaps for purposes of this Note are highlighted in order to allow application of the frustration of purpose doctrine.

22. Calculation: (0.05 Fixed Rate * \$25 Loan Principal for 1st Term) - (0.04 LIBOR Rate * $\$ 25$ Loan Principal for 1 st Term $)=\$ 0.25$ payment from Business A to Bank 1 .

23. Calculation: (0.05 Fixed Rate * \$25 Loan Principal for 2nd Term) - (0.07 LIBOR Rate * $\$ 25$ Loan Principal for 2 nd Term) $=\$-0.50$ payment from Business A to Bank 1 (in other words, Bank 1 owes Business A $\$ 0.50$ for this term). 
a reduction in the interest rate below 5 percent. Theoretically, Bank 1 will enter into interest rate swap transactions in which it believes Business A will end up paying the difference between the LIBOR rate and the fixed rate (i.e. when LIBOR falls below the fixed rate) more often than it will have to pay the difference to Business A (i.e. when LIBOR rises above the fixed rate). For Business A, it can calculate a reasonably fixed cost for the bond, which allows better budgeting and financial planning: when adding what it receives from or pays to Bank 1 with what it owes Bank 2 on the Corporate Bond Rate, it should come out to approximately a 5 percent total interest payment.

\section{An Overview of The Global Financial Crisis of 2007 and 2008}

The global financial crisis of 2007 and 2008 created a "fundamental disruption" and a "financial upheaval" that "wreaked havoc in communities and neighborhoods across the country." 24 Since then, there has been much debate amongst politicians, academics, and the general populous concerning who exactly is at fault for the meltdown. ${ }^{25}$ The government-created Financial Crisis Inquiry Commission made a determination in 2011 that it was indeed a combination of factors amalgamating to create the drastic effect. Amongst these factors were the practice of shadow banking, the increase in securitization and derivatives, the deregulation of the financial and banking industries, and increases in subprime lending. ${ }^{26}$ Of importance to this Note is the "conclu[sion that] over the counter derivatives contributed significantly to th[e] crisis," and an understanding of how the downturn directly affected interest rate swaps in a significant way. ${ }^{27}$

\section{The Effect of the Global Financial Crisis on Interest Rate Swaps in America: Divergence Causes a Hedging Failure}

As America experienced its financial spiral, floating interest rate indexes plummeted. This brought about an "unforeseen and precipitous drop in interest rates ... . [causing the impairment of] borrowers' (as Fixed Rate Payors) financial position under their swap contracts, causing them to owe substantial interval, settlement, and/or early termination payments to

24. The Financial Crisis Inquiry Comm'n, The Financial Crisis Inquiry Report:

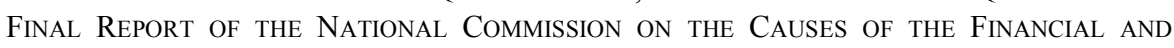
ECONOMIC CRISIS IN THE UNITED STATES XV (2011).

25. Id. at xvii; see also Brenda Cronin, Economists Debate Financial Crisis Causes, Cures, Wall ST. J. (Dec. 14, 2011, 5:15 PM), http://www.blogs.wsj.com/economics/2011/ 12/14/economists-debate-financial-crisis-causes-cures/, archived at http://perma.cc/K9Y5LH5E.

26. See The FinAnCial Crisis InQuiry COMM'N, supra note 24, at xv-xxviii.

27. The FinANCIAL CRisis InQuiry COMM'N, supra note 24, at xxiv (alterations added). 
their counterparty Floating Rate Payors. ${ }^{, 28}$ These index rate drops turned the interest rate swaps into consistent losers for the parties who had the fixed rate, as each term ended with the LIBOR or the index rate below the fixed rates. ${ }^{29}$ The inverted effect of this was a windfall for the institutions holding the floating rate. ${ }^{30}$ However, the loss by the fixed rate holders due to the hedging was a foreseeable risk that those parties had knowingly taken on as part of their agreement. What was not foreseen and what caused these holders to lose on a much larger scale was the divergence of the Corporate Bond Rate and the LIBOR rate. ${ }^{31}$ Recall that a basic assumption for the effectiveness of an interest rate swap as a hedge is that the indexing rate, such as LIBOR, and the Corporate Bond Rate will track one another; that did not happen during the financial crisis. ${ }^{32}$ Instead, the company had to pay the historic difference between the low indexing rate and the unmoving fixed rate to the bank - in the previous example, Bank 1-as part of the swap agreement. ${ }^{33}$ But in addition, the company had to pay a large amount to the holder of the bond-in the previous example, Bank 2-at the Corporate Bond Rate since the Corporate Bond Rate increased or held steady, and the indexing rate plummeted; the companies stuck in these transactions were paying two parties and effectively there was no hedge. ${ }^{34}$

Recalling the example used previously with Business A, Bank 1, and Bank 2, it is once again easier to visualize the loss of a hedge with numerical values. As a reminder, assume that Business A pays a fixed rate set at 5 percent to Bank 1. For this example, Business A's corporate bond is $\$ 100$ and the Corporate Bond Rate is tied to the Federal Funds Rate, while the indexing rate is LIBOR. Finally, recall that LIBOR and the Corporate Bond Rate or here, the Federal Funds Rate set by the Federal Reserve, need to track. Assume for the first twenty-five-dollar term, the LIBOR rate is 4 percent, the Corporate Bond Rate is 4.25 percent, and the fixed rate is the standard 5 percent; for this term, Business A makes a $\$ 0.25$ payment to Bank 1 and must pay Bank $2 \$ 1.06 .^{35}$ Under these conditions, the hedge

28. Jaimee Newman, Impact of the Financial Crisis on Fixed Rate Swap Payors, New ENG. Real Estate J. (Nov. 2010, archived at http://perma.cc/GE4W-JELE) (alterations added).

29. See Matthew Jensen, The Uses of LIBOR and the Victims of Its Manipulation: A Primer, AMERICAN (Aug. 23, 2012, archived at http://perma.cc/6A6S-Y6HG).

30. Id.

31. Kimberly Amadeo, LIBOR Rate History: LIBOR Compared to the Fed Funds Rate During the Financial Crisis, ABOUT.COM, http://useconomy.about.com/od/ monetarypolicy/a/history_LIBOR.htm (last updated Sept. 16, 2013, archived at http://perma.cc/6VPU-7GBG).

32. Id.

33. Id.

34. Id.

35. Calculation: (0.05 Fixed Rate * \$25 Loan Principal for 1 st Term) - (0.04 LIBOR rate $* \$ 25$ Loan Principal for 1 st Term $)=\$ 0.25$ payment from Business A to Bank 1 and 
works because Business A is paying a total rate of 5.25 percent, which is near the 5 percent fixed rate. However, assume that between the first and second term the financial crisis occurs. When it comes time for the second payment, the fixed rate is still 5 percent, LIBOR has plummeted to 2 percent, and the Corporate Bond Rate has also fallen, but to 3.5 percent; LIBOR and the Corporate Bond Rate are no longer closely tracking. For this term, Business A must pay Bank $1 \$ 0.75$ and must pay Bank $2 \$ 0.88 .^{36}$ Under these conditions, the hedge has failed and Business A must pay 6.52 percent for this term instead of their fixed 5 percent. For this transaction, it may not seem like much of a difference; however, for a larger dollar volume corporate bond and over the course of multiple terms, this higher payment could be a large blow for a business.

Moving on to the third term, assume that conditions continue to deteriorate and LIBOR has fallen to 1 percent while the Corporate Bond Rate falls to 3.25 percent; although both rates have fallen, the difference between the rates has increased even more. In this term, the hedge has failed again and Business A must pay Bank $1 \$ 1.00$ and must pay Bank 2 $\$ 0.81 .^{37}$ The total rate paid for the term is 7.24 percent. In the fourth term, assume that the LIBOR rate fell to 0.5 percent and the corporate bond rate fell to 3 percent. For this term, Business A owes Bank 1 \$1.12 and Bank 2 $\$ 0.75$, for a total payment of $\$ 1.87$ and a total rate of 7.48 percent. $^{38}$

As this example demonstrates, an unexpected and unprecedented divergence in the LIBOR rate and Corporate Bond Rate all with a falling LIBOR rate increases the "fixed" interest rate the borrower was supposed to pay. On a large scale, even seemingly small divergences can create drastic losses. This is what occurred during the financial crisis of 2007 and 2008. For example, from January of 2006 until June of 2006, the difference between LIBOR $^{39}$ and the Federal Funds Rate hovered between 0.2 percent

(0.0425 Corporate Bond Rate * $\$ 25$ Loan Principal for 1 st Term $)=\$ 1.06$ payment from Business A to Bank 2. The total payment for Business A in the 1 st Term is $\$ 1.31$ or $5.25 \%=$ (\$1.31 Total Payment / \$25 Loan Principal for 1st Term).

36. Calculation: (0.05 Fixed Rate * \$25 Loan Principal for 2nd Term) - (0.02 LIBOR rate $* \$ 25$ Loan Principal for 2nd Term $)=\$ 0.75$ payment from Business A to Bank 1 and (0.035 Corporate Bond Rate * \$25 Loan Principal for 2 nd Term $)=\$ 0.88$ payment from Business A to Bank 2. The total payment for Business A in the 2nd Term is $\$ 1.63$ or $6.52 \%$ $=(\$ 1.63$ Total Payment $/$ \$25 Loan Principal for 2nd Term $)$.

37. Calculation: (0.05 Fixed Rate * $\$ 25$ Loan Principal for 3rd Term) - (0.01 LIBOR rate $* \$ 25$ Loan Principal for 3rd Term $)=\$ 1.00$ payment from Business A to Bank 1 and $(0.0325$ Corporate Bond Rate * $\$ 25$ Loan Principal for 3rd Term $)=\$ 0.81$ payment from Business A to Bank 2. The total payment for Business A is $\$ 1.81$ or $7.24 \%=(\$ 1.81$ Total Payment / \$25 Loan Principal for 3rd Term).

38. Calculation: (0.05 Fixed Rate * $\$ 25$ Loan Principal for 4th Term) - (0.005 LIBOR Rate $* \$ 25$ Loan Principal for 4th Term $)=\$ 1.87$ payment from Business A to Bank 1 and $(0.03$ Corporate Bond Rate $* \$ 25$ Loan Principal for the 4th Term $)=\$ 0.75$ payment from Business A to Bank 2. The total payment for Business A is $\$ 1.87$ or $7.48 \%=(\$ 1.87$ Total Payment / \$25 Loan Principal for 4th Term).

39. References to LIBOR in this Note refer specifically to the 3 Month LIBOR Rate. 
and 0.25 percent. ${ }^{40}$ However, once the crisis hit in September of 2007, the difference was much higher, reaching at its height a difference of 2.8 percent in October of $2008 .^{41}$

\section{The Legal Ramifications in The United States: A Legal Barricade from Recovery}

After the divergence between the Corporate Bond Rates and LIBOR, entities attempted to recover from their drastic losses. They began by attempting to bring lawsuits against the banks, but they ran up against the built-in legal safeguards of the standardized ISDA agreements they had signed. $^{42}$ The International Swaps and Derivatives Association (ISDA) standardized the form of swap agreements in an attempt to reduce disputes and transaction costs associated with the deals. ${ }^{43}$ However, the ISDA agreement is only one of three parts of an agreement, the other two being the Schedule and the Confirmation Letter. ${ }^{44}$ These three documents combined tend to insulate the banks from claims after a loss occurs, as they include many waivers on the part of the entity entering into the deals with the banks. ${ }^{45}$ Furthermore, a large majority of American litigation in the derivatives arena falls under the jurisdiction of the Federal District Court for the Southern District of New York and New York state law as a result of the form documents offered by the banks. ${ }^{46}$

\section{a. Lack of Authority or Agency}

One of the more common claims brought in attempts to invalidate swap agreements, at least initially, was that the execution on the part of the company was performed with a lack of authority or agency. In such cases, the customer claims that the employee or employees who entered into the transaction did not have the corporate authority to engage in that level of decision-making. ${ }^{47}$ The claim relies on "the assertion that the employee was somehow a renegade and the corporation was unaware of what was actually

40. Amadeo, supra note 31.

41. Amadeo, supra note 31.

42. Kim, supra note 6, at 752-53; see also Victor Vital \& Aimee M. Minick, Swap Agreements: The Who, What, Where, When and Why of Litigating a Swap Case, 1, 14-15, http:/www.martindale.com/members/Article_Atachment.aspx?od=291099\&id=247408\&file name $=$ asr-247410.pdf, archived at http://perma.cc/8SGE-8CN5 .

43. Kim, supra note 6 , at 752.

44. Kim, supra note 6, at 753-54.

45. Kim, supra note 6, at 753-54.

46. Vital \& Minick, supra note 42 , at $9,15$.

47. Aaron Rubinstein, Common Law Theories of Liability in Derivatives Litigation, 66 FORDHAM L. REV. 737, 741 (1997). 
being done." ${ }^{48}$ However, these claims were not widely successful due to the doctrine of apparent authority, which places liability on a company or employer that gives a false impression that the employee engaged in the transaction does have the authority to execute the deal; it is a theory that promotes reasonable reliance on a person's authority when he or she purports to be a decision maker. ${ }^{49}$ For apparent authority to not apply in such a situation, the facts would require a person of questionable authority involved in the transaction to begin with, which is not likely considering the impliedly important nature of these hedging techniques. ${ }^{50}$

As a typical example of how US courts deal with agency claims in this context, Ables \& Hall Builders (Ables) attempted to avoid its losses due to interest rate swaps by claiming a lack of authority to enter the agreement. ${ }^{51}$ Ables had entered into a swap with US Bank National Association, which brought a breach of contract action to enforce the payment terms of the swap against Ables. ${ }^{52}$ As a defense against enforcement, Ables claimed that Darlene, a bookkeeper, did not have authority to bind the company with the interest rate swap transaction yet proceeded to sign the Master Agreement and Schedule. ${ }^{53}$ The bank realized a while later that Darlene had not been authorized to sign on behalf of Ables, and it contacted Ables to have the contract officially executed. ${ }^{54}$ Eventually, Ables consented to sign the forms again; however, there was some question as to whether management fully understood the agreement. ${ }^{55}$ The court found that, by performing under the contract for over three years after execution, Ables had ratified the agreement in terms of agency law. ${ }^{56}$ The court did not discuss whether Darlene may have had apparent authority. ${ }^{57}$ This case emphasizes the struggle an entity has in utilizing this legal defense against enforcement. Even if the court somehow determines that there was a lack of apparent authority on the part of an employee, the barrier of ratification by performance makes this legal tool virtually obsolete in instances where the transaction has already begun.

\section{b. Fraud}

In addition to agency claims, entities trying to recover from interest

48. Id.; see also Partnoy, supra note 15, at 470-74.

49. See Rubinstein, supra note 46 , at $741-42$.

50. Rubinstein, supra note 46, at 741-42.

51. See U.S. Bank Nat'l Ass'n v. Ables \& Hall Builders, 696 F. Supp. 2d 428, 437 (S.D.N.Y. 2010).

52. Id. at 433 .

53. Id at 435 .

54. Id.

55. Id. at 435-36.

56. Id. at 439 .

57. Id. 
rate swaps gone wrong have attacked the formation of the transaction, saying that the bank either engaged in fraud or a negligent misrepresentation. The fraud claims are highly case-specific and can become very complex to resolve in the derivatives context. ${ }^{58}$ Because of the relatively difficult and complicated nature of derivatives, it can be difficult to prove that a misunderstanding, on the part of a business entity, was a material misstatement made by the bank. ${ }^{59}$ Businesses have attempted to assert fraud in everything from a misrepresentation of the nature of the risks involved to a misrepresentation of the value of the derivatives. ${ }^{60}$

Even in a less financially volatile time with fewer claims, American courts have not given much heed to fraud arguments relating to interest rate swaps. In Procter \& Gamble Co. v. Bankers Trust Co., an Ohio federal court held that a transaction for interest rate swaps did not constitute fraud. ${ }^{61}$ Procter \& Gamble (P \& G) argued that Bankers Trust Co. (BT) had represented to them, through advertisements and presentations, that they would be using expertise in the area to advise them in the complex area of derivatives. ${ }^{62}$ The court found that

BT was not acting for or on behalf of P \& G as that relationship is generally construed in the customer-broker context. As counterparties, P \& G and BT were principals in a bilateral contractual arrangement. This is not to say that BT had no duties to P \& G. . . However, P \& G has no private right of action under $\S 4 \mathrm{~b}$ [of the Commodity Exchange Act]. ${ }^{63}$

In K3C Inc. v. Bank of America, N.A., the Fifth Circuit Court of Appeals also determined that there was not an action for fraud in the transaction for an interest rate swap. ${ }^{64}$ The court emphasized the stringent standard to be met in order for the plaintiff to succeed on the fraud claim saying,

To prevail on their fraud claim, [K3C, Inc.] must prove that: (1) BOA made a material representation that was false; (2) BOA knew the representation was false or made it recklessly as a positive assertion without any knowledge of

58. Partnoy, supra note 15 , at 462-63.

59. Partnoy, supra note 15 , at 462-63.

60. Rubinstein, supra note 47 , at 744 .

61. Procter \& Gamble Co. v. Bankers Trust Co., 925 F. Supp. 1270, 1286 (S.D. Ohio 1996).

62. $I d$.

63. Id. (alterations added).

64. K3C Inc. v. Bank of America, N.A., 204 F. App'x 455, 463 (5th Cir. 2006). 
its truth; (3) BOA intended to induce [K3C, Inc.] to act upon the misrepresentation; and (4) [K3C, Inc.] actually and justifiably relied upon the representation and thereby suffered injury. ${ }^{65}$

The Fifth Circuit's opinion further cemented the trouble in overcoming the burden of proving fraud when it mentioned that the language contained in the ISDA Master Agreement makes it difficult to prove the justifiable reliance prong. ${ }^{66}$ Although as a general rule fraud claims have not found much success in this arena, most parties seeking to recover for losses on interest rate swaps bring a fraud claim since the facts of the individual case could potentially bring a different outcome. ${ }^{67}$

\section{c. Negligent Misrepresentation}

Though closely related to fraud, negligent misrepresentation claims are a slightly different method of approaching recovery from a losing interest rate swap. In order to succeed on a negligent misrepresentation claim, an injured plaintiff must show the defendant breached a duty to the plaintiff. ${ }^{68}$ In a commercial context, such as that of the derivatives market, the defendant must possess some form of expertise or be in a position of trust with the injured party such that reliance on the defendant's negligent misrepresentation was warranted. ${ }^{69}$ Typically, those entities bringing negligent misrepresentation claims allege that the marketing campaign of the financial institution has portrayed the transaction in a simpler and less risky manner than is appropriate; this is despite the typical contractual language in which the business agrees that it is fully informed of what it is entering into and discloses the potential for financial loss. ${ }^{70}$ Furthermore, "[t]he law of negligent misrepresentation is more complex than that of fraud and generates some additional difficulties in derivatives disputes." ${ }^{, 71} \mathrm{~A}$ similar but subtly different corollary to this argument has come more recently in the form of attempts to void the transactions as an equitable remedy due to the LIBOR-rigging scandal occurring at the same time that banks were still selling and marketing interest-rate swaps. Under this theory, a party often claims that the banks were negligently misrepresenting

65. Id. (alterations added).

66. "Moreover, even if the Companies proved that BOA made a false material representation, the Companies' reliance on that representation would not have been justifiable in light of the explicit disclaimer of reliance in the Master Agreement." Id.

67. Rubinstein, supra note 47 , at 744.

68. Partnoy, supra note 15 , at 468.

69. Partnoy, supra note 15 , at 468.

70. Partnoy, supra note 15, at 468.

71. Partnoy, supra note 15, at 468 (alteration added). 
that the swaps worked as a hedge when those swaps already executed were failing due to artificial LIBOR deflation. ${ }^{72}$

Cases previous to the financial crisis demonstrated that negligent misrepresentation claims were not likely to get past the safeguards of ISDA. Additionally, the barrier of a counterparty relationship between the banks and those entering the transaction with them and a difficulty in proving statements that constitute a negligent misrepresentation combine to largely discount this cause of action. ${ }^{73}$ After the crisis, there was little to no change in this outcome. ${ }^{74}$ Additionally, statute of limitations issues add another obstacle to recovery under negligent misrepresentation. ${ }^{75}$

The court in Yountville Investors, LLC v. Bank of America, N.A. provides an opinion demonstrating the difficulty parties have in bringing negligent misrepresentation claims. ${ }^{76}$ After their interest rate swap cost Yountville Investors dearly, they brought several claims for declaratory relief, restitution, and damages. ${ }^{77}$ Yountville alleged "defendant possesse[d] 'unique and specialized expertise and superior knowledge with respect to interest swap agreements[,]' and therefore had a duty to disclose any profit it would realize on entering the agreement, as well as to 'correctly represent the manner and method by which it calculated any termination amount.",78 The court, however, dismissed the claim saying,

Even viewing the facts alleged by plaintiff in the most favorable light, the Court finds that plaintiff has failed to allege either a relationship that is in any way distinct from that between a "plain-vanilla" borrower and lender, or a duty of care arising from any source external to the swap agreement. The law does not impose liability for negligent

72. See Harry Wilson, Barclays in Court Over Mis-selling Claims, TelegraPH (Oct. 28, 2012, archived at http://perma.cc/BBH4-97QA).

73. "On appeal, $[\mathrm{K} 3 \mathrm{C}$, Inc. has] not identified any statements of fact . . that were actually false. . . [or] were so incomplete as to be misleading. Nor, where [Bank of America] representatives made statements of opinion, have Appellants shown that [they] did not genuinely possess those opinions." K3C Inc. v. Bank of America, N.A., 204 F. App'x. 455, 462 (5th Cir. 2006) (alterations added); "[A]lleged misrepresentations that contradict the express words of a written instrument are inadmissible to avoid an obligation knowingly assumed." St. Matthew's Baptist Church v. Wachovia Bank Nat'l Ass'n, No. Civ.A. 04-4540 (FLW), 2005 WL 1199045, at *5 (D.N.J. May 18, 2005) (explaining that the Master Agreement contained language precluding a negligent misrepresentation claim) (alteration added).

74. See Regions Bank v. SoFHA Real Estate, Inc., No. 2:09-CV-57, 2010 WL 3341869 (E.D. Tenn. Aug. 25, 2010); see also Yountville Investors, LLC v. Bank of America, N.A, No. C08-425RSM, 2009 WL 2342462 (W.D. Wash. July 28, 2009).

75. See, e.g., K3C Inc., 204 F. App'x. at 462.

76. See Yountville Investors, LLC, 2009 WL 2342462 at *3.

77. $I d$.

78. Id. at $* 6$ (alterations added). 
misrepresentations in such a context. Plaintiff's claim for negligent misrepresentation must therefore be dismissed. ${ }^{79}$

In general, negligent misrepresentation claims for interest rate swaps end up meeting the same end as most other traditional claims brought against the behemoth that is the financial system and its built-in legal protections.

\section{The Effect on Interest Rate Swaps in the United Kingdom: A Similar Divergence Issue Overseas}

The effects of the financial crisis of 2007 and 2008 were not isolated to the United States of America. ${ }^{80}$ When the US government allowed the investment bank Lehman Brothers to fail in September of 2008, the crisis came to a global head; for a period, every bank was considered to be risky. ${ }^{81}$ Shortly thereafter, there were legitimate fears of a global financial domino effect; this fear forced western governments to serve as capital life support for many of their banks in order to avoid collapse. ${ }^{82}$ It is in this financial background that interest rate swaps became losing transactions in the United Kingdom just as they had in the United States. ${ }^{83}$ In England alone, an estimated 28,000 interest rate swaps were sold to small businesses between the years of 2001 and $2007 .{ }^{84}$

\section{The Legal Ramifications in the United Kingdom: A More Friendly Recovery Regime}

There are two main distinguishing factors between judicial determinations relating to interest rate swaps in the United States and the United Kingdom. The first was the decision handed down in Hazell $v$. Hammersmith and Fulham London Borough Council by the House of Lords in $1991{ }^{85}$ Hazell was a unanimous determination by the highest court of

79. Id. at *9.

80. See Larry Elliott, Global Financial Crisis: Five Key Stages 2007-2011, GuARDiAN (Aug. 7, 2011, 11:49 AM), http://www.guardian.co.uk/business/2011/aug/07/globalfinancial-crisis-key-stages, archived at http://perma.cc/KU9Y-72W9.

81. Id.

82. Id.

83. See Matt Scuffham \& Myles Neligan, Special Report: UK Banks Face Scandal Over Toxic Insurance Products, REUTERs (Aug. 22, 2012, 7:24 AM), http://www.reuters.com/article/2012/08/22/us-banks-insurance-idUSBRE87L09E20120822, archived at $\mathrm{http}: / /$ perma.cc/U4AX-UZYG.

84. Id.

85. Hazell v. Hammersmith and Fulham London Borough Council, [1991] 2 W.L.R. 372 (H.L.) (appeal taken from Eng.). 
appeal in the United Kingdom ${ }^{86}$ that the interest rate swaps at issue were ultra vires of the local authorities who had entered into them and thus illegal. $^{87}$ The second aspect that separates the legal ramifications of the global financial crisis on interest rate swaps in the United Kingdom versus the United States is the judicial handling of claims for restitution or rescission since the crisis. In the United Kingdom, it is possible such claims are more likely to succeed due to both the rise of mis-selling claims after the LIBOR scandal has come to $\operatorname{light}^{88}$ and the Financial Services Authority (FSA) process for payouts to uninformed purchasers of the swaps. ${ }^{89}$

\section{a. The Hazell Decision and its Fortunate Consequences}

Although both businesses and local governments have utilized interest rate swaps as a funding mechanism in the United States, the Hazell case in 1991 removed local governments from the market in the United Kingdom. The decision would seem a fortuitous piece of foresight after the global financial crisis turned several swap transactions into toxic losers. In Hazell, the Hammersmith and Fulham London Borough Council ceased making payments toward the interest rate swaps they had entered into. ${ }^{90}$ At the time, this was the largest default on an interest rate swap transaction in history. ${ }^{91}$ The Local Government Act of 1972 divided England into counties, districts, London boroughs, and parishes; it also created the Hammersmith and Fulham London Borough Council and other similar local bodies. ${ }^{92}$ The authority of these local bodies was circumscribed by the 1972 Act specifically limiting the purpose and methods of borrowing for local authorities. $^{93}$ The Council entered into several interest rate swaps through

86. At the time of the Hazell decision, the House of Lords was the highest court of appeal in the United Kingdom. However, in 2009 the government separated the judiciary and Parliamentary functions of the House of Lords and endowed the judicial authority of the highest court of appeal on the Supreme Court. See From House of Lords to Supreme Court, PARLiAMENT (July 23, 2009), http://www.parliament.uk/business/news/2009/07/from-houseof-lords-to-supreme-court/, archived at http://perma.cc/Y6YE-NWZF.

87. Hazell, 2 W.L.R. 372, at*3.

88. See Lucy McCann, Swap Mis-selling: Grant Estates Ltd (in Administration) v. The Royal Bank of Scotland PLC, IN-House LAWYER (Nov. 6, 2012), http://www.inhouselawyer.co.uk/index.php/scotland-home/10018-swap-mis-selling-grantestates-ltd-in-administration-v-the-royal-bank-of-scotland-plc, archived at http://perma.cc/TT89-LPPJ; see also Julia Werdigier, UBS Posts \$2 Billion Loss Tied to Legal Settlements, N.Y. TIMES (Feb. 5, 2013, 2:13 AM), http://dealbook.nytimes.com/ 2013/02/05/ubs-posts-2-billion-loss-on-libor-fines/, archived at http://perma.cc/4NNMJVX4.

89. See Scuffham \& Neligan, supra note 83 .

90. Dan Fischer, supra note 14, at 513.

91. Dan Fischer, supra note 14, at 513.

92. Dan Fischer, supra note 14, at 518-19.

93. Dan Fischer, supra note 14, at 519. 
the years in an attempt to correctly predict the rise or fall of interest rates and earn a profit on the transactions in order to apply the earnings to the interest of their borrowing. ${ }^{94}$

On January 24, 1991, the House of Lords determined all of the Council's interest rate swaps were illegal and invalid. ${ }^{95}$ The court interpreted the 1972 Act to not include interest rate swaps as an ancillary or incidental function of the Council's borrowing power. ${ }^{96}$ As a result of the swap transactions being ultra vires, the Council was excused from making its contractually obligated payments of $\$ 843.5$ million to $\$ 1.012$ billion to the banks with which it had entered into the transactions. ${ }^{97}$

Despite the immediate impact of the Council's ability to excuse payment, there was a much broader and longer-lasting effect stemming from the Hazell decision. There were two central consequences arising from the decision. First, the local authorities in the United Kingdom no longer entered into interest rate swaps. ${ }^{98}$ This would be important a decade and a half later when English local authorities and institutions watched as their US counterparts suffered through bankruptcy or financial stress nearing bankruptcy as a result of toxic swaps. ${ }^{99}$ The second, more chaotic action was a "triggering of a rash of litigation." ${ }^{\text {"To }}$ Once the Hazell decision came down, it unraveled hundreds of other transactions entered into by other local authorities as ultra vires. ${ }^{101}$ Overall, the central effect of the Hazell decision on the global financial crisis in 2007 and 2008 was that when the crisis hit, some local governments in the US were damaged severely by holding interest rate swaps while the local authorities in the United

94. Dan Fischer, supra note 14, at 519.

95. Dan Fischer, supra note 14, at 528.

96. Dan Fischer, supra note 14, at 528.

97. Dan Fischer, supra note 14, at 528-29. The valuation of the excused payments rely on the currency exchange calculation performed by the author of the cited article. The British value of the excused payments was $£ 500$ to $£ 600$ million. Dan Fischer, supra note 14, at 528-29.

98. Garry J. Schinasi et al., Modern Banking and OTC Derivatives Markets: The Transformation of Global Finance and its Implications for Systemic Risk 28 (2000).

99. See The Big Losers in the Libor Rate Manipulation: Local Governments Which Entered Into Interest Rate Swaps Got Scalped, Ritholtz.com (July 5, 2012, 1:30 AM), http://www.ritholtz.com/blog/2012/07/the-big-losers-in-the-libor-rate-manipulation/, archived at http://perma.cc/P5GH-LL3M; see also Craig Douglas, Boston University Gets \$200 Million Capital Call Amid Interest Rate Swoon, Bos. Bus. J. (Oct. 19, 2012, 4:39 PM), http://www.bizjournals.com/boston/news/2012/10/19/boston-university-gets-200m-capital.html, archived at http://perma.cc/KZB4-B5E7; Michael McDonald et al., Harvard Swaps are So Toxic Even Summers Won't Explain (Update3), BloOMBERG.COM (Dec. 18, 2009, 4:28 PM), http://www.bloomberg.com/apps/news?pid=newsarchive\&sid=aHQ2Xh55jI.Q, archived at http://perma.cc/N5Z9-YQPE.

100. See SCHINASI ET AL., supra note 98, at 28.

101. SCHINASI ET AL., supra note 98, at 28. 
Kingdom had been banned from entering such arrangements since 1991.

\section{b. The Rise of Mis-Selling Claims}

More recently, the divergence between the handling of interest rate swap disputes in the United Kingdom and the United States has increased with the prevalence of what the British financial world has dubbed "misselling." 102 The reason behind the term is the idea that the banks selling and marketing the transactions did not make clear the consequences of a drop in one of the tracking rates more than the other, and that they had not revealed initially the penalty-sized termination fees in the event the company needed to end the contract early. ${ }^{103}$ Though nominally different, the claim for misselling closely mirrors the American common law negligent misrepresentation or fraud claims. ${ }^{104}$ A stark difference is the general success realized by British companies in bringing these claims versus their American counterparts.

With claims for mis-selling from all forms and sizes of businesses, the FSA $^{105}$ has taken on the task of sifting through the interest rate swap swamp in the United Kingdom. It is easiest to sort the mis-selling claims into two categories: those utilizing the LIBOR-rigging scandal as a central part of the mis-selling argument and those claims not necessarily focused on the LIBOR-rigging scandal. It is important to note that both of these areas of British law are rapidly changing as multitudes of these claims are raised, judicially or administratively determined, or settled virtually daily. ${ }^{106}$

The claims of mis-selling made without a focus on the LIBOR scandal have been relatively successful depending on the business bringing the claim. In 2012 the large public concern in the United Kingdom over the havoc interest rate swaps had wreaked on small and medium-sized companies (SMEs) culminated in a review of the transactions by the

102. See Scuffham \& Neligan, supra note 83 .

103. Scuffham \& Neligan, supra note 83.

104. See supra Section $\mathrm{II}(\mathrm{C})(2)(\mathrm{c})$.

105. The FSA is an independent agency charged with regulating the financial services industry in the United Kingdom. The FSA has rule-making, investigatory, and enforcement powers. About the FSA, FIN. SERVICES AUTH., http://webarchive.nationalarchives.gov.uk/ 20130201171633/http://www.fsa.gov.uk/about (archived in Feb. 2013, archived at http://perma.cc/8ZP3-DC4Q). Note that the FSA became two separate regulatory agencies: The Financial Conduct Authority and the Prudential Regulation Authority during the publication process of this Note. About the FSA, FIN. SERVICES AUTH., http://www.fsa.gov.uk/about (last updated Mar. 23, 2013, archived at http://perma.cc/6WUA-3KMQ). As such, consider all references to the FSA in the Note as references to the FSA prior to its split.

106. See e.g., Interest Rate Swap Mis-Selling Claims, Cooke, Young, \& KeIDAn, http://www.cyklaw.com/interest-rate-swap-mis-selling-claims (last visited Feb. 7, 2014, archived at http://perma.cc/PUC6-QZKK) (an example of a law firm specifically advertising its ability to handle these claims). 
FSA. ${ }^{107}$ At that time, a number of banks based in the United Kingdom ${ }^{108}$ agreed with the FSA to provide appropriate remedies without a suit in instances of mis-selling. ${ }^{109}$ Part of the reason for the banks' acquiescence was the FSA's finding that 90 percent of deals with unsophisticated purchasers violated at least one of the FSA's rules. ${ }^{110}$ The question then arose about what to do with the claims not based on LIBOR manipulation in court having been brought by SMEs prior to the banks' agreements with the FSA. ${ }^{111}$ An answer came in the form of a decision in Grant Estates, Ltd. v. The Royal Bank of Scotland. ${ }^{112}$ In that case, the court held that the contract forming the interest rate swaps precluded a mis-selling claim, similar to the results in American courts; this left Grant Estates, Ltd. solely with a remedy through the agreements between the FSA and the banks for restitution. ${ }^{113}$

Although it was clear that the banks would be compensating SMEs for the mis-selling of interest rate swaps, as of January 31, 2013, there was not an established method or calculation of how the payments were to be made or administered, though payments under non-terminated agreements had been suspended. ${ }^{114}$ Additionally, there were certain specifications for the SMEs that would be eligible under the agreements. Originally, the FSA determined only businesses with less than $£ 6.5$ million of sales, fewer than fifty employees, or assets worth less than $£ 3.26$ million would be eligible. ${ }^{115}$ The purpose of this classification was to hopefully capture only the subset of businesses that were non-sophisticated and would not be likely to have understood the full financial complexities of an interest rate swap. ${ }^{116}$ Inversely, the FSA did not want to bail out companies that had the financial complexity and capacity to understand the risky transaction they were entering. ${ }^{117}$ However, the FSA soon realized that this was an oversimplification and that categorizing businesses in this way did not best

\footnotetext{
107. McCann, supra note 88 .

108. Included in the list of banks making such an agreement with the FSA were: Barclays, HSBC, Lloyds, NatWest, and the Royal Bank of Scotland. See McCann, supra note 88. Later, more banks were added, including Santander, Co-operative Bank, Allied Irish Bank, Bank of Ireland, Clydesdale and Yorkshire banks, and Northern Bank. See James Hurley, FSA Extends Probe Into Rate Swap Mis-selling Scandal, Telegraph (July 23, 2012, 11:28 AM), http:/www.telegraph.co.uk/finance/yourbusiness/9420370/FSA-extends-probeinto-rate-swap-mis-selling-scandal.html, archived at http://perma.cc/JDF6-4UX6).

109. McCann, supra note 88.

110. Banks to Pay for 'Swap' Mis-selling, FSA Demands, BBC News (Jan. 31, 2013, 8:32 AM), http://www.bbc.co.uk/news/business-21272606, archived at http://perma.cc/AR8D-FGTC.

111. McCann, supra note 88 .

112. McCann, supra note 88 .

113. McCann, supra note 88 .

114. Banks to Pay for 'Swap' Mis-selling, FSA Demands, supra note 110.

115. McCann, supra note 88.

116. McCann, supra note 88.

117. See Banks to Pay for 'Swap' Mis-selling, FSA Demands, supra note 110.
} 
serve the purpose sought. ${ }^{118}$ An example of this strict categorization would be a company that operated a seasonal business and had more than fifty employees due to a large amount of work in a small amount of time; more specifically, an institution like a bed and breakfast ${ }^{119}$ or a small orchard might be classified as complex enough to understand the inner-workings of an interest rate swap. ${ }^{120}$ From a policy-perspective, the FSA knew it must change course; the exact nature of this change in categorization is still being contemplated as of the writing of this Note. ${ }^{121}$

Furthermore, there has been much debate on how those SMEs qualifying for the FSA agreement with the banks will be compensated. The FSA has made a general statement expressing that redress for mis-selling of interest rate swaps "should aim to put customers back in the position they would have been in, had the breach of regulatory requirements not occurred." 122 The company must demonstrate it would not have purchased an interest rate swap had the bank not mis-sold in order to receive full compensation or that it would have purchased a different product for partial compensation. ${ }^{123}$ Those aspects of compensation may seem straightforward, but many SMEs also desire compensation for consequential damages stemming from their toxic swap contracts. Some of the claims for consequential damages include requests for compensation due to laying off employees, selling off assets, overdrafting charges, or additional borrowing costs; termination fees are typically considered to be a direct damage from the swap transactions. ${ }^{124}$ At this stage, it is unclear exactly how the consequential damages will factor into redress for mis-selling. ${ }^{125}$

By excluding larger, more complex companies from utilizing the FSA agreement with the banks, the FSA prompted a new type of mis-selling claim; one that focuses on the artificial deflation of the LIBOR rate during the global financial crisis. At the time of the writing of this Note, it is not exactly clear how the courts in the United Kingdom will handle mis-selling cases in which the impropriety of LIBOR depression by the bank involved in the transaction is utilized as a justification for restitution. However, there are indications that the banks are concerned with what the future might hold. For example, Barclays set aside $\$ 1.6$ billion for legal costs it anticipated for mis-selling claims as of February 5, 2013-including a large portion not allocated for forced payments through its agreement with the

118. Banks to Pay for 'Swap' Mis-selling, FSA Demands, supra note 110.

119. Banks to Pay for 'Swap' Mis-selling, FSA Demands, supra note 110.

120. Banks to Pay for 'Swap' Mis-selling, FSA Demands, supra note 110.

121. Banks to Pay for 'Swap' Mis-selling, FSA Demands, supra note 110.

122. Banks to Pay for 'Swap' Mis-selling, FSA Demands, supra note 110.

123. Banks to Pay for 'Swap' Mis-selling, FSA Demands, supra note 110.

124. Banks to Pay for 'Swap' Mis-selling, FSA Demands, supra note 110.

125. Banks to Pay for 'Swap' Mis-selling, FSA Demands, supra note 110. 
FSA to restore SMEs to pre-swap position. ${ }^{126}$ Additionally, UBS reported that it had spent $\$ 2$ billion on legal fees in 2012; this included \$1.5 billion in fines for its role in the LIBOR-rigging scandal in addition to fighting other legal battles related to the scandal. ${ }^{127}$ One final demonstration of how large banks might fear legal precedent for LIBOR-rigging claims is The Royal Bank of Scotland, which settled for $£ 25$ million with businessman David Agar over his interest rate swap claims. ${ }^{128}$

\section{THE CARNAGE: REAL EXAMPLES OF THE GLOBAL FINANCIAL DESTRUCTION DUE TO TOXIC INTEREST RATE SWAPS}

It is difficult to overstate the devastating financial consequences the crisis in 2007 and 2008 and the conditions that followed have had on businesses, local governments, and other "fixed rate" holders of derivatives, most specifically interest rate swaps. Jefferson County in Alabama, which contains the city of Birmingham, underwent the largest municipal bankruptcy on record due to its derivatives used to finance sewage improvements in 2008. ${ }^{129}$ Boston University suffered at the hand of interest rate swaps to the tune of a net operating loss of $\$ 162.6$ million for fiscal year 2011; this forced the university to ready and liquidate \$200 million in the event that it had to cancel the transactions and pay termination fees. ${ }^{130}$ Even worse was neighboring Harvard University, whose interest rate swaps became so toxic that it was willing to terminate them at a fee of around $\$ 1$ billion. ${ }^{131}$ Businesses from Wisconsin's Metavante, which supplied financial technology services and software to the British Chinese restaurant chain Hakkasan, lost considerable amounts of money on interest rate swaps. ${ }^{132}$ It was under this climate of financial annihilation and loss that disenchanted and disgruntled entities brought legal claims attempting to

126. Mark Scott \& Julia Werdigier, Barclays Sets Aside \$1.6 Billion More for Legal Costs, N.Y. Times (Feb. 5, 2013, 3:02 AM), http://dealbook.nytimes.com/2013/02/05/ barclays-sets-aside-extra-1-6-billion-for-legal-costs/, archived at http://perma.cc/4ZGQS76U.

127. Werdigier, supra note 88.

128. Harry Wilson, RBS Pays More Than $£ 25 m$ to Businessman David Agar Over Interest Rate Swaps, TELEGRAPH (July 28, 2012, 9:36 PM), http://www.telegraph.co.uk/finance/newsbysector/banksandfinance/9434489/RBS-paysmore-than-25m-to-businessman-David-Agar-over-interest-rate-swaps.html, archived at http://perma.cc/9KC5-8YWK.

129. The Big Losers in the Libor Rate Manipulation: Local Governments Which Entered Into Interest Rate Swaps Got Scalped, supra note 100.

130. Douglas, supra note 99.

131. McDonald et al., supra note 99.

132. See Harry Wilson, Restaurant Boss Starts Pay Revolt on Bank Swaps, TelegRAPH (Nov. 25, 2012, 7:00 AM), http://www.telegraph.co.uk/finance/newsbysector/retailand consumer/9700596/Restaurant-boss-starts-pay-revolt-on-bank-swaps.html, archived at http://perma.cc/JR7K-5QTT. 
recover anything they could get their hands on.

\section{THE Frustration OF PURPOSE DOCTRINE: A SEEMINGLY INAPPLICABLE APPLICATION}

\section{A. The Tests for Frustration of Purpose: A Common Law Defense to Enforcement}

As a relatively rare common law defense to enforcement, frustration of purpose may seem like an unlikely theory to enter the complicated and complex derivatives market as a savior for holders of toxic swaps. However, applying the facts of the recent and unprecedented global financial crisis within the interest rate swap context to a frustration scenario, it actually makes quite a bit of sense as a claim against enforcement.

The Restatement (Second) of Contracts states that the frustration of purpose doctrine applies:

Where, after a contract is made, a party's principal purpose is substantially frustrated without his fault by the occurrence of an event the non-occurrence of which was a basic assumption on which the contract was made, his remaining duties to render performance are discharged, unless the language or the circumstances indicate the contrary. ${ }^{133}$

The rationale behind this defense to enforcement of a contract is to protect a party when the other party's performance becomes virtually worthless due to something unforeseen to either party prior to agreeing to the deal. ${ }^{134}$ It is crucial first that the purpose being frustrated was the principal purpose or consideration of the contract; in other words, without the existence of the frustrated portion of the contract, the transaction would have made little sense. ${ }^{135}$ Additionally, the frustration must not be slight; rather, it must be of a substantial nature. ${ }^{136}$ Finally, the non-occurrence of the frustrating event must have been so strongly assumed that it was a basic assumption upon which the contract was made. ${ }^{137}$

In essence, the doctrine of frustration of purpose is a judicially imposed condition on all contracts that both parties agree at the time of contracting that either party will be excused from performance if the conditions change in a way unforeseen to either party in a way relating to

133. Restatement (SECOND) OF CONTRACTS $§ 265$ (1981).

134. Id. § $265 \mathrm{cmt}$. a.

135. Id.

136. Id.

137. Id. 
something that is a fundamental basis of the deal. ${ }^{138}$ In order for frustration of purpose to apply, the value of the parties' performance must be completely or almost completely abrogated by the frustrating event. ${ }^{139}$ The rationale behind the foreseeability requirement is that if the occurrence of the frustrating event is reasonably foreseeable, then the parties to the contract should have negotiated terms addressing the potential occurrence of the event and indicating which party would bear the burden or risk of its occurrence. ${ }^{140}$ Furthermore, the general view amongst the legal community is that " $[t]$ he doctrine of commercial frustration should be limited in its application and narrowly applied to preserve the certainty of contracts."

\section{B. The Beginning of the Frustration of Purpose Doctrine: A Cancelled Parade}

The history of the frustration of purpose doctrine in both America and the United Kingdom actually took root in the same decision. Krell v. Henry is the archetypal case for frustration of purpose and finds itself in most firstyear contract law courses. ${ }^{142}$ In Krell, the two parties to the lawsuit had entered into a contract in which Mr. Henry would rent Mr. Krell's apartment for two days. ${ }^{143}$ Though not expressed in the language of the contract, the principal purpose of the rental was for Mr. Henry to view the coronation parade of the King from Krell's balcony apartment. ${ }^{144}$ The intent behind the renting was evidenced by the short term of the rental and the fact that the "price to be paid . . . was fixed with reference to the expected procession"-in other words, at a much higher price than would typically be the case. ${ }^{145}$ When it came time for the parade, the King fell ill and the parade did not take place as planned. ${ }^{146} \mathrm{Mr}$. Henry refused to pay for the room as the contract required, and this suit commenced. ${ }^{147}$

The court ultimately held that Mr. Henry did not have to pay for the room as agreed upon in the contract. ${ }^{148}$ The court set the following parameters for determining whether frustration of purpose should excuse enforcement of a contract:

Each case must be judged by its own circumstances. In

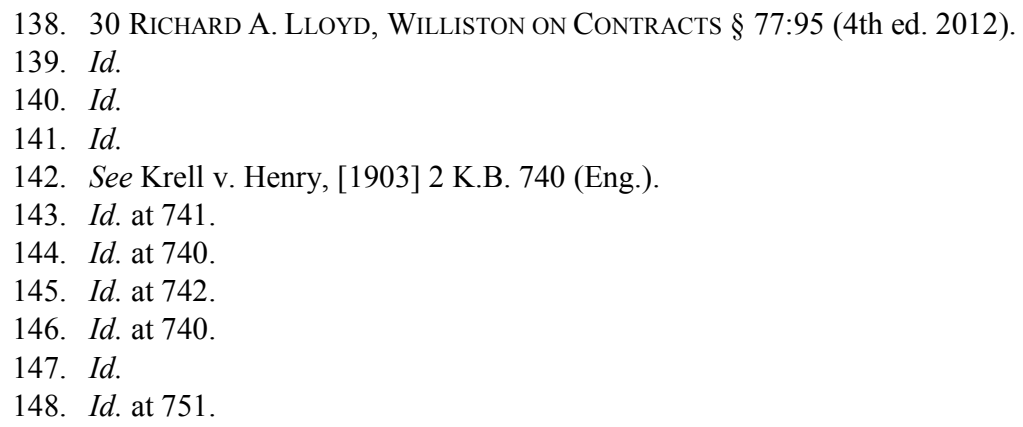


each case one must ask oneself, first, what, having regard to all the circumstances, was the foundation of the contract? Secondly, was the performance of the contract prevented? Thirdly, was the event which prevented the performance of the contract of such a character that it cannot reasonably be said to have been in the contemplation of the parties at the date of the contract? If all these questions are answered in the affirmative ...., I think both parties are discharged from further performance of the contract. ${ }^{149}$

When applying the facts of the case to that framework, the court determined that the basis of the contract was to rent the room in order to view the coronation. ${ }^{150}$ The non-occurrence of the coronation prevented the performance of the contract in that the bargained-for consideration was no longer in existence. ${ }^{151}$ Finally, the event frustrating the agreement, or the cancellation of the coronation, was not something the parties would have reasonably foreseen when agreeing to the terms of the contract; in other words, there was a presumption by both parties that the procession would occur and the non-occurrence was reasonably determined to be so unlikely that the contract did not specifically state that the contract was conditioned on the occurrence of the coronation. ${ }^{152}$

\section{The Current Relevance of the Frustration of Purpose Doctrine}

Frustration of purpose is generally rare as an affirmative defense to the enforcement of a contract. It does, however, have a contemporary application, ${ }^{153}$ especially within the confines of New York state law, which governs most interest rate swaps under ISDA form agreements. There are many different types of contracts in which performance is excused under frustration of purpose, and even seemingly complex business and financial contracts between seemingly knowledgeable and experienced parties can result in frustration of purpose. ${ }^{154}$ The particular context is of little importance; rather, as long as the elements for frustration of purpose are present, the defense to enforcement is valid.

In D\&A Structural Contractors Inc., the court found frustration of

149. Id.

150. Id. at 746 .

151. Id. at 747 .

152. Id. at $743-44$.

153. See D\&A Structural Contractors Inc. v. Unger, No. 001112-08, 2009 WL 3206596 (N.Y. Sup. Ct. Aug. 20, 2009); see also 528-538 W. 159th St. LLC v. Soloff Mgt. Corp., No. 3778/05 (N.Y. Sup. Ct. May 3, 2010); State Mut. Life Assur. Co. v. Gruber, 54 N.Y.S.2d 729 (App. Div. 1945).

154. For examples, see cases listed in supra note 153. 
purpose a legitimate defense to enforcement in the insurance context. ${ }^{155}$ More specifically, a married couple had their mutual property destroyed by a fire. ${ }^{156}$ The wife entered into a contract for the restoration of the destroyed house, with the contracted price to be the insurance proceeds. ${ }^{157}$ However, prior to the contract, the couple had become estranged and initiated a divorce; as such, the matrimonial court prohibited the wife from transferring any of her marital assets, which included the insurance proceeds. ${ }^{158}$ The divorce proceedings and the restraint on the distribution of the insurance money prevented the wife from paying on the contract, and a lawsuit followed. ${ }^{159}$ The court ultimately held that her performance was excused since the court order preventing her from disbursing the insurance proceeds had frustrated the purpose of the contract to rebuild the house. ${ }^{160}$ The court determined that "the central element of the Restoration Contract was the renovation of the home." 161 Essentially, "[the wife's] objective was to renovate her home with the insurance proceeds, and this was the basis upon which [the parties] contracted."162 As such, the court "conclude[d] that the issuance of the restraining order was an unanticipated event that frustrated the contracts' purpose, thereby discharging [the wife's] obligation to make payment pursuant to the ... [contract]."163

Another recent example of a New York court enforcing the frustration of purpose doctrine comes in 528-538 W. 159th St. LLC. ${ }^{164}$ In this case, Soloff Management was hired to manage a set of apartment buildings. ${ }^{165} \mathrm{In}$ a breach not related to frustration of purpose, an action was commenced in which an arbitration administered by the traditional Jewish arbitration panel dubbed the Beis Din was to arbitrate based upon Din Torah, or Jewish law. ${ }^{166}$ Two of the three arbitrators on the Beis Din removed themselves from the arbitration, which led to a whirlwind of reshuffling amongst the Jewish leaders and an ultimate determination that the Beis Din was unable to make a judicial decision since they could not compel discovery of essential information to the issue. ${ }^{167}$ These facts led the court to excuse the parties from arbitration, since "the Beis Din [was] unable to fully arbitrate

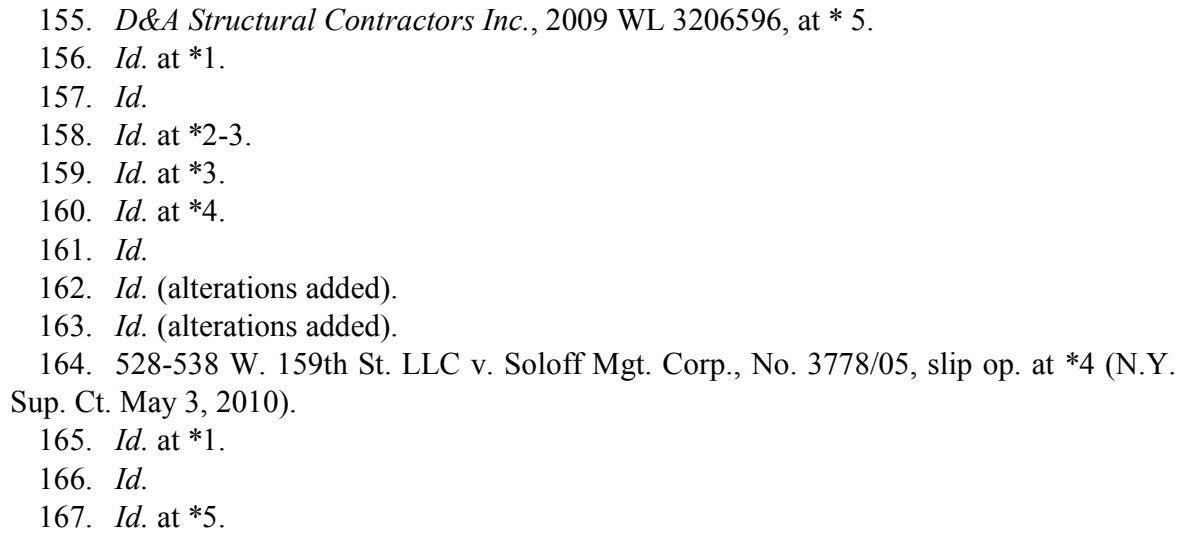


the dispute, which [was] the obvious purpose of the agreement." 168 Overall, the court determined that "defendants' failure to complete discovery has frustrated the entire purpose of the arbitration agreement." 169

D. Murphy-Hoffman Co. v. Bank of America, N.A. Brings the Frustration of Purpose Doctrine into the Realm of Interest Rate Swaps

Murphy-Hoffman Co. v. Bank of America, N.A. ${ }^{170}$ is a little-known piece of case law with drastic importance for utilizing a commercial frustration argument to unwind an interest rate swap. It is not necessarily significant in terms of judicial precedent; rather, its functional use is as a guidepost for how to structure the argument. The decision was made by the US District Court for the Western District of Missouri using New York law for the frustration of purpose claim. ${ }^{171}$ Murphy-Hoffman Co. (MH) sold and leased trucks at a variety of facilities across ten states. ${ }^{172}$ Bank of America (BoA) approached $\mathrm{MH}$ about the possibility of entering into an interest rate swap in order to insure that $\mathrm{MH}$ had a fixed interest rate for the money it had recently borrowed. ${ }^{173}$ BoA gave a presentation to $\mathrm{MH}$ in which BoA demonstrated how the transaction would benefit $\mathrm{MH} .{ }^{174}$ In the explanation, $\mathrm{MH}$ was informed that the purpose of the transaction was to hedge its floating interest rate. ${ }^{175}$

After and during the global financial crisis, the hedging function of the interest rate swap failed and $\mathrm{MH}$ stopped paying BoA. ${ }^{176}$ Essentially, the two floating rates generally tracked as they were supposed to from the inception of the agreement until 2007. ${ }^{177}$ However, from September 2007 until MH terminated the transactions in March of 2009, the two floating rates substantially diverged from one another and caused the transaction to be an ineffective hedge for $\mathrm{MH} .{ }^{178} \mathrm{MH}$ was forced to pay a high variable interest rate for its original loan while not receiving an equally high variable interest rate as a result of the interest rate swap. ${ }^{179}$

In its claim for frustration of purpose, $\mathrm{MH}$ stated that both parties

168. Id. at $* 7$ (alterations added).

169. Id.

170. Murphy-Hoffman Co. v. Bank of America, N.A., No. 09-00227-CV-W-FJG, 2009 WL 2524773 (W.D. Mo. Aug. 14, 2009).

171. Id. at $* 1, * 5$.

172. Id. at *1.

173. Id.

174. Id.

175. Id.

176. Id.

177. Id.

178. Id.

179. Id. 
were aware that an interest rate hedge was the purpose of the agreement. ${ }^{180}$ However, MH also alleged that neither party was aware that the tracking rates would substantially diverge. ${ }^{181}$ In an argument to have the frustration of purpose claim dismissed, BoA argued that the theory did not apply because the frustrating event was foreseeable. ${ }^{182}$ In the eyes of BoA, the parties had both contemplated loss as a risk of the agreement due to the difference between MH's fixed rate payments to BoA and BoA's floating rate payments to $\mathrm{MH} .{ }^{183}$ As an additional argument, BoA claimed that since the agreement was based on something that was inherently risky, volatile, and contingent on many factors, the frustration of purpose doctrine should not unwind the agreement. ${ }^{184}$

After determining that $\S 265$ of the Restatement (Second) of Contracts would provide the elements ${ }^{185}$ of the theory for frustration of purpose, the court determined that the central issue of contention was the foreseeability of the divergence. ${ }^{186}$ As the court was simply making a determination on a motion to dismiss the claim, it did not need to make an official determination as to the foreseeability; rather, it held "[w]hile $[\mathrm{MH}]$ could certainly foresee losses from engaging transactions within the swap agreement, it is entirely plausible that neither party reasonably foresaw the divergence between the interest rate indices. ${ }^{" 187}$ In its explanation, the court emphasized the difference between the interest rate swap-which was inherently risky - and the overall strategy to hedge the floating interest rate-which was not purported to be inherently risky. ${ }^{188}$ As an illustrative point of this distinction between foreseeability and non-foreseeability, the court brought up the case of Strauss v. Long Island Sports, Inc., a case based on legendary NBA basketball player Julius "Dr. J" Erving and a trade sending him to another team. ${ }^{189}$ As the court in Strauss explained, a season ticket holder bringing a frustration of purpose claim must fail because the possibility of a player trade is foreseeable. ${ }^{190}$ In its conclusion that it would deny BoA's motion to dismiss the frustration of purpose claim, the court profoundly stated,

\footnotetext{
180. Id. at *3.

181. Id.

182. Id.

183. Id.

184. Id.

185. "A party's principal purpose is substantially frustrated without his fault by the occurrence of an event the non-occurrence of which was a basic assumption on which the contract was made." Id. at *4.

186. Id.

187. Id. (alterations added).

188. Id.

189. Id. (citing Strauss v. Long Island Sports, Inc., 60 A.D.2d 501, 504 (N.Y. App. Div. 1978)).

190. Strauss, 60 A.D.2d at 510-11.
} 
It is plausible that nearly identical movements of the two floating rates was not an uncertain or contingent event; in fact, it would make sense that the rates would track each other given that the tracking of the two floating rates would be necessary to effectively hedge .... ${ }^{191}$

Unfortunately for those seeking some form of a definitive answer as to whether this common law theory can invalidate highly structured and complex financial instruments, Murphy-Hoffman Co. did not substantively proceed past BoA's motion for dismissal. ${ }^{192}$ Instead, the two parties reached a settlement, and the case was dismissed with prejudice by a stipulation from $\mathrm{MH} .{ }^{193}$ With an undisclosed settlement agreement, it is unclear what the motivation was for BoA in failing to fight a lawsuit over interest rate swaps when all relevant case law was on its side. It raises a question as to whether BoA was more concerned specifically with the frustration of purpose claim; after all, the other claims brought by $\mathrm{MH}$ were not anything with much likelihood of success given legal precedents. It could be that BoA simply provided $\mathrm{MH}$ a small offer, and $\mathrm{MH}$ accepted it to recover something from its losses. However, if the terms of the settlement were substantial, BoA could have been guarding against legal precedent accepting frustration of purpose as a legitimate claim for recovery and opening the floodgates for litigation and payouts for all toxic interest rate swaps.

Even without a definitive answer from the US District Court for the Western District of Missouri as to whether MH's interest rate swaps were rescinded due to commercial frustration of purpose, one might have still expected the litigation floodgates to open after the claim passed muster for a motion to dismiss. However, the decision in Murphy-Hoffman Co. allowing the frustration of purpose claim was handed down in August of 2009. ${ }^{194}$ Since then, there has not been another decision in any American jurisdiction taking the claim further. This begs the question of why a newly successful claim in a realm of unsuccessful attempts at recovery has not become a mainstream method for unwinding interest rate swaps affected by the global financial crisis. A simple search in an electronic legal database such as Westlaw demonstrates that there is no negative legal treatment of the decision to allow the frustration of purpose claim in Murphy-Hoffman Co. ${ }^{195}$ One possible explanation could be that the claims have come prior to litigation and have been settled once the banks realized the potential

191. Murphy-Hoffman Co., 2009 WL 2524773, at *4 (alteration added).

192. See Docket, Murphy-Hoffman Co. v. Bank of America, N.A., 2009 WL 2524773 (No. 4:09-CV-00227).

193. Id.

194. Murphy-Hoffman Co., 2009 WL 2524773.

195. See id. 
dangers of fighting and losing a frustration of purpose battle.

There is some support for the theory that banks are eager to settle in order to avoid case law allowing frustration of purpose. The Superior Court of North Carolina in Mecklenburg County allowed a frustration of purpose claim to survive a motion to dismiss in Press Communications, LLC v. Wachovia Bank, N.A. ${ }^{196}$ In an attempt to recover from toxic swaps, Press Communications filed a brief in response to the defendant's motion to dismiss the complaint, citing Murphy-Hoffman Co. ${ }^{197}$ The case settled after the motion to dismiss was denied. ${ }^{198}$ Additionally, a claim of frustration of purpose in an interest rate swap transaction was transferred to the US District Court for the Middle District of North Carolina. ${ }^{199}$ Once again, the party seeking to avoid the swaps cited the decision in Murphy-Hoffman Co. ${ }^{200}$ Unsurprisingly, the case was settled outside of court early on in the process and Overlook Properties, L.P. stipulated to a dismissal. ${ }^{201}$

\section{E. Wells Fargo Bank, N.A. V. CTD Moorefield Retail, LLC and the Potential for a Definitive Answer}

Although to this point there has not been a definitive resolution to the question of whether a frustration of purpose claim will routinely succeed in unwinding an interest rate swap, there is a chance that an answer is on the way. Wells Fargo Bank, N.A. v. CTD Moorefield Retail, LLC is currently pending in the US District Court for the Northern District of Texas. ${ }^{202}$ However, the case started in the US District Court for the Southern District of New York. ${ }^{203}$ While in the Southern District of New York, a motion to dismiss the frustration of purpose claim alleged by CTD Moorefield Retail, LLC was denied. ${ }^{204}$ The question becomes whether this case goes as the others of this ilk and ends in settlement in order to prevent the Northern District of Texas from making a decision under New York law, or whether

196. Order on Motion to Dismiss, Press Commc'ns, LLC v. Wachovia Bank, N.A. (No. 09-CVS-21335), 2010 WL 8749672, (N.C. Super. Apr. 12, 2010).

197. Plaintiff's Brief in Opposition to Defendant's Motion to Dismiss, Press Commc'ns, LLC v. Wachovia Bank, N.A. (No. 09-CVS-21335), 2010 WL 8749672 (N.C. Super. Apr. 12, 2010).

198. Order on Motion to Dismiss, Press Commc'ns, LLC v. Wachovia Bank, N.A. (No. 09-CVS-21335), 2010 WL 8749672 (N.C. Super. Apr. 12, 2010).

199. Response in Opposition to Suntrust Bank's Motion for Judgment On the Pleadings, Overlook Properties, L.P. v. Suntrust Bank, No. 11CV00662, 2012 WL 6725053, (M.D.N.C. Feb. 16, 2012) (No. 11CV00662).

200. Id.

201. See Docket, Overlook Properties, L.P. v. Suntrust Bank, 2012 WL 6725053 (M.D.N.C. Feb. 16, 2012) (No. 11CV00662).

202. See Docket, Wells Fargo Bank, N.A. v. CTD Moorefield Retail, LLC, 3:2012-CV01219.

203. Id.

204. Id. 
the court has the opportunity to provide a more clear answer as to whether the claim is sufficient to pass stricter scrutiny than a mere motion to dismiss.

\section{Putting it All Together}

The global financial crisis fundamentally changed the LIBOR rate and the range in which it generally cycles. ${ }^{205}$ Years later, it has come to light that the international banking community may have colluded to artificially depress this rate. ${ }^{206}$ At the same time, many businesses found ever rising Corporate Bond Rates. Ultimately, the businesses were paying twice on their loans: once for the differences between LIBOR and the fixed rate in their interest rate swaps to the banks and once for the differences between LIBOR and the Corporate Bond Rate to the loaning parties on their bond transactions. ${ }^{207}$ The Corporate Bond Rate was so much higher than LIBOR that at a point, the consideration for the interest rate swaps initially — the hedging — was no longer functioning. ${ }^{208}$

It is yet to be determined whether the courts will generally recognize the validity of the commercial frustration of purpose defense to interest rate swaps. To this point, the cases have settled or been withdrawn before a verdict has been handed down. This, however, may not change anytime soon. If banks determine that they do not want to risk the chance that this defense becomes precedential, then they may settle when parties bring this cause of action. A separate dimension to this claim is the statute of limitations. Since commercial frustration of purpose is a common law contract defense, its statute of limitations might follow the same track, which could be six years, for example. The issue to be settled would be whether the frustration occurs at one point in time or whether it is a continuous frustration; that finding would be crucial to determine when the statute of limitations begins tolling. With a six-year statute of limitations, it is possible that time is running short for many parties looking to make a recovery from a deal in place during 2007 and 2008. At the same time, it is possible that with the now-recognizable risk that the floating interest rate indexes might diverge, a party could succeed by arguing that there is a continuous frustration of purpose for the transaction; the transaction had lost its hedging capability at any moment within a certain time frame.

In addition to the concerns surrounding the statute of limitations running out on transactions in place during the global financial crisis, there

205. See supra Section II(C)(1).

206. James O'Toole, Explaining the Libor Interest Rate Mess, CNN Money (July 10, 2012, 12:07 PM), http://money.cnn.com/2012/07/03/investing/libor-interest-rate-faq/, archived at http://perma.cc/BA8U-JTZA.

207. See supra Section $\mathrm{II}(\mathrm{C})(1)$.

208. See supra Section II(C)(1). 
are also questions about damage calculations if the claims succeed. One possibility is that courts would place parties in the positions they were in previous to entering into the agreement. Another possibility is that the termination fee would be the only portion included in recovery. It is unlikely that a court would award consequential damages due to the general reluctance to award these in most circumstances; however, the consequential damages have been extensive in some instances. For example, if a company became financially strapped, it might have taken out an additional loan to cover the interest rate payments. There is an endless list of damages one can think of being caused by a massive and unexpected cost of doing business. As with statute of limitation issues, the damage calculation might turn on the exact moment the swap's purpose was frustrated. Overall though, one would think that many of the businesses affected by the toxic interest rate swaps will likely accept any relief they can recover within reason at this point.

Factoring in the unresolved issues of statutes of limitations, damage calculations, and the other complexities of unraveling a detailed financial derivative, this Note contends that from a purely legal perspective, interest rate swaps operating during the global financial crisis and tied to floating rates that diverged like LIBOR and the Federal Funds Rate should be held unenforceable under the frustration of purpose doctrine. It should be noted that this argument is more relevant currently for the American legal system. In the United Kingdom, many of the losers from interest rate swaps have been afforded restitution either through the FSA agreement with the banks, or through the still-pending decisions on whether LIBOR-rigging banks will be punished for selling interest rate swaps at the same time. In America, however, the companies and local governments who have lost in their interest rate swap transaction can really only hold out hope for success through the frustration of purpose doctrine.

Given the background information regarding the legal theory of frustration of purpose provided earlier in this Note, there are three chief reasons why the doctrine should successfully be applied to interest rate swaps during the global financial crisis. As an aside, one can assume with rather inarguable certainty that the only contested element of the frustration of purpose argument in this context is that of reasonable foreseeability. The principal purpose, or the hedging function, was substantially frustrated without any doubt. The individual institution entering into the interest rate swap did not have any way of being at fault for the loss of the hedging. The remaining question is whether the loss of a hedging function was an event the non-occurrence of which the parties had assumed at the time of the transaction. It is this question that can be answered with three contentions. The first is that the non-occurrence of the loss of hedging was unforeseen due to the unprecedented magnitude of the global financial crisis. The second is that it was unforeseen that many of the largest lenders in the world would artificially manipulate the LIBOR rate. Third, it was not 
foreseeable that the American federal government would move the Federal Funds Rate to an astonishingly low rate and choose to bail out the financial institutions and banks with drastic consequences for small businesses and local or small government institutions.

The global financial crisis was both unexpected and unexpected in extent. It was not foreseeable that the global economy would crash, nor that rates that had historically tracked very closely would suddenly diverge exponentially. Typically, the indexes would vary by between zero and $.25 \%$, with rare occurrences of divergences of more than that. However, during the Financial Crisis, the divergence reached new heights. It is safe to say that an unprecedented event, rivaling only the Great Depression, would not have been planned for in the interest rate swap contracts. Neither party to the transaction would have reasonably believed it necessary to include language for the occurrence of such a crisis. The clearest way to prove the assertion that the contracts for interest rate swaps were founded on the basis that the hedging function would not fail due to a divergence in the floating rates stems from the fact that the transactions were entered into to begin with; why would a company or local government enter into a hedging transaction geared toward avoiding risk with knowledge that it was potentially increasing its interest rate exposure with a rate divergence?

Although artificial depression of the LIBOR rates would not have increased the divergence between the floating rates once the Federal Reserve began lowering the Federal Funds rate, the manipulation of one of the floating rates exposed the hedge to a new risk. The hedging of interest rate exposure was substantially frustrated - there was a great unforeseen risk once the banks began illegally controlling the rate - and the hedging function was no longer a reasonably secure hedge. The "LIBOR Market" was not a true reflection of the rate at which the banks were able to borrow. What made the LIBOR manipulation egregious was that many of the same banks illegally deflating the LIBOR rate were also selling and marketing interest rate swaps as properly functioning hedging mechanisms. If they sold the swaps while LIBOR was deflated artificially, they knew or should have known that there was a chance the rate would return to an accurate rate and then the divergence in floating rates would increase; this would, of course, destroy the hedging function of the interest rate swaps they had sold while the rate was depressed. The LIBOR manipulators were an unbargained-for variable in the interest rate swap transactions; it was not foreseeable that banks would illegally cause the hedging functions of these contracts to fail.

Finally, it was not foreseeable that the Federal Reserve would historically and precipitously reduce the Federal Funds Rate in an attempt to stave off the economic downturn. In response to the global financial crisis, the Federal Reserve precipitously lowered the Federal Funds Rate to zero percent, where it has remained since. The issue with that is the rate had been around four percent before the crisis hit. As the Federal Funds Rate 
plummeted, there was not a chance that LIBOR would be able to keep up in its fall for swaps tied between these two rates; the result was a large divergence and a frustration of the hedging purpose in many interest rate swaps. Even if one were to argue that a global financial crisis was a foreseeable event at the time of entering the swaps, it would be difficult to say that in the event of such a crisis, the Federal Reserve would allow the Federal Funds Rate to drop so low and at such a quick pace.

Although the arguments against frustration of purpose as applied to interest rate swaps during the global financial crisis should not succeed, it is interesting to analyze the failures of the swaps. The main contention is that the presumed knowledge and expertise of the entities agreeing to the swaps with the banks demonstrates foreseeability. In other words, the complexity of the organizations entering into the swaps indicated that they knew or should have known that the interest rates might not track. However, this presumes too much. Just because a business or its decision makers might have complex and advanced knowledge of banking or business, that does not mean that they would know about the inner-workings of interest rate swaps. Even if they did know how the swaps worked, historic numbers demonstrated that the tracking would not fail.

\section{CONCLUSION}

Overall, it may be that many types of interest rate swaps will become a derivative dinosaur and claims for recovery will be irrelevant. However, the entities still suffering from the effects of the swaps during the global financial crisis are searching for recovery and restitution now. As a legal theory for unwinding interest rate swaps, the frustration of purpose doctrine only suffers from its unusual position in the realm of a complex global financial market, a stigma that may give pause to courts that have consistently held for the large financial institutions and the formal ISDA contracts. For the time being, whether in the United Kingdom or the United States, there are questions unanswered as to whether there is a road to recovery from the grand losers of the global financial crisis. 
